\title{
BAGAIMANA PEMANFAATAN KETERBATASAN TEKNOLOGI UNTUK MENINGKATKAN KECERDASAN INTERPERSONAL
}

\author{
Viva Juwita \\ Magister Pendidikan Matematika FKIP Universitas Tanjungpura
}

Email korespondensi: Vivajuwita05@gmail.com

\begin{abstract}
Abstrak
$10.26418 /$ pipt.2021.6

Tujuan penelitian ini adalah untuk melihat bagaimana pemanfaatan komunikasi sosial dan untuk memahami lingkungan di sekitarnya. Dengan terbatasnya teknologi yang ada di SMP Negeri 2 Sungai Pinyuh maka penelitian ini berusaha mengangkat bagaimana keterbatasan teknologi untuk meningkatkan kecerdasan interpersonal. Penelitian didasari oleh keterbatasan teknologi yang ada di SMP Negeri 2 Sungai Pinyuh. Salah satu kecerdasan yang dibutuhkan siswa saat ini adalah kecerdasan interpersonal, seperti kemampuan dalam mengatasi keterbatasan teknologi dalam pembelajaran untuk meningkatkan kecerdasan interpersonal. Walaupun keterbatasan tetap ada, seharusnya tetap dapat meningkatkan kecerdasan interpersonal diri. Penelitian ini menggunakan pendekatan kualitatif, hasilnya dipaparkan secara deskriptif. Eksplorasi data dengan mencari literatur lima sampai sepuluh tahun terakhir. Data dari penelitian ini diperoleh dari studi literatur yang relevan, dan berkaitan langsung dalam peningkatan kecerdasan interpersonal diri dengan keterbatasan teknologi yang ada. Kemudian hasilnya dianalisis secara deskriptif. Hasil dari penelitian ini menunjukkan bahwa teknologi yang terbatas tidaklah menghambat dalam meningkatkan kecerdasan interpersonal siswa. Dengan demikian, diharapkan para guru yang berada di daerah yang memiliki keterbatasan teknologi dapat memanfaatkan media yang ada di lingkungan sekitar mereka.
\end{abstract}

Kata kunci: teknologi, pemanfaatan teknologi, keterbatasan teknologi, kecerdasan interpersonal dan kecerdasan interpersonal diri.

\section{PENDAHULUAN}

Tulisan ini yang berjudul "Bagaimana Pemanfaatan Keterbatasan Teknologi untuk Meningkatkan Kecerdasan Interpersonal”. Tujuan dari penulisan ini adalah untuk melihat apakah dengan keterbatasan teknologi yang ada, dapat meningkatkan kecerdasan sosial atau interpersonal diri dan menambah pengetahuan wawasan dari siswa.

Ilmu pengetahuan yang berkembang dewasa ini mempunyai pengaruh yang sangat besar terhadap dunia pendidikan, terutama dalam proses pendidikan di sekolah. Dengan berkembangnya teknologi dunia pendidikan harus mampu mengikuti perkembangan jaman, namun perkembangan teknologi tidak semua dapat di nikmati oleh siswa yang mengalami kesulitan di bidang teknologi. Dengan keterbatasan teknologi yang di alami oleh siswa seorang pendidik harus mampu memberikan jalan keluar yang terbaik bagi siswanya, misalnya memberikan lembar kerja bagi peserta didik, agar siswa tersebut tidak mengalami kesulitan dalam proses belajar mengajar, sehingga siswa tidak mengalami keterhambatan dalam kemajuan teknologi, sehingga siswa tidak mengalami keterhambatan dalam meningkatkan kecerdasan interpersonal diri.

Kecerdasan Interpersonal adalah bagaimana seseorang melakukan interaksi agar dapat saling mengerti dengan orang lain, dan dengan dirinya sendiri sehingga dapat menghargai orang lain.

Dalam menyikapi suatu masalah terhadap seseorang untuk saling berinteraksi, diperlukan orang lain. Kecerdasan interpersonal harusnya dapat membuat seseorang mampu untuk menyesuaikan diri dengan orang lain baik dari aspek budaya, toleransi, sikap empati, sehingga dapat melakukan hubungan multikultural. Kecerdasan interpersonal dengan kata lain adalah kecerdasan dalam berkomunikasi sosial dapat diartikan sebagai kemampuan seseorang dalam berinteraksi pada kedua 
belah pihak dan saling berbagi, sehingga dapat saling menerima satu dengan yang lainnya. Jika seseorang dapat menyesuaikan diri dan orang lain serta dapat saling memahami maka akan dapat saling berinteraksi untuk menyesuaikan diri, untuk berempati dan saling memberi kebaikan bersama.

Ciri-ciri seseorang yang mempunyai kecerdasan interpersonal adalah jika ada saling perbedaan maka yang bersangkutan akan mudah untuk menyesuaikan diri dan bisa memahami perbedaan tersebut dengan baik dalam lingkungan sendiri maupun di lingkungan sekitarnya (Maksum, 2011).

\section{Kecerdasan Interpersonal}

Seperti yang telah dijelaskan di dalam pendahuluan bahwa kecerdasan interpersonal adalah suatu kecerdasan yang dimiliki oleh seseorang agar saling memahami antara satu dan yang lainnya dan dapat memberikan masukan kepada sesama agar terjadi hubungan untuk saling berkomunikasi serta bekerjasama dan saling berinteraksi, (Prasetyo \& Andriyani, 2009). Menurut Thordnike cit. Azwar (2004) di dalam kecerdasan interpersonal, setiap orang memiliki sikap yang berbeda untuk saling menghargai serta mempunyai kemampuan saling menghormati sehingga tidak ada yang dirugikan.

Menurut Prasetyo \& Andriyani (2009) kecerdasan interpersonal meliputi:

a. Mempunyai hati nurani untuk saling menghargai kepada sesama,

b. Sebagai team-work dalam bekerja,

c. Saling berbagi informasi dalam berkomunikasi,

d. Mampu menjadi seorang pemimpin dan dapat menyelesaikan masalah yang terjadi,

e. Dapat memberikan jalan tengah jika dalam menyelesaikan suatu masalah.

Sesuai pendapat Gardner cit. Muzayanah \& Prestiana (2008) kecerdasan interpersonal memiliki tiga keutamaan dan menjadikan untuk saling terkait satu sama yang lainnya yaitu: a) Rasa sensitif individu yaitu kemampuan dalam menghayati perubahan yang terjadi antar sesama teman. b) Dapat menyelesaikan masalah yang terjadi yang tidak menghambat sesama teman atau relasi. c) Dapat berkomunikasi dengan baik sehingga membangun hubungan interpersonal yang baik.

Dengan membangun komunikasi yang baik akan memudahkan dalam penggunaan teknologi di dalam kehidupan bermasyarakat. Walaupun di jaman sekarang teknologi sudah mengalami perkembangan dan kemajuan sehingga dapat dijadikan sebagai sumber pembelajaran, namun tidak semua teknologi dapat dicapai dan terwujud. Namun kondisi ini dapat dilakukan dengan keterbatasan teknologi tidak akan menghambat kecerdasan interpersonal pada para siswa yang ada di lingkungan SMP Negeri 2 Sungai Pinyuh.

Dengan pemanfaatan keterbatasan teknologi yang ada, pembelajaran dapat di lakukan dengan melihat dan menggunakan media yang ada di lingkungan sekitarnya sehingga keterbatasan teknologi yang ada bisa dimanfaatkan sebagaimana semestinya.

Di lapangan menunjukkan, dengan keterbatasan teknologi dapat mempengaruhi dunia pendidikan dan proses pembelajaran baik kualitas maupun dalam mutu pendidikan. Seorang pendidik dapat melakukan berbagai cara untuk mengatasi dengan keterbatasan teknologi yang ada misalkan dengan membuat LKPD pembelajaran yang di sesuaikan dengan lingkungan sekitarnya. Namun itu tidak akan terjadi jika keterbatasan teknologi dapat dimanfaatkan melalui pemanfaatan dari teknologi itu sendiri apabila kita dapat memanfaatkannya di dunia pendidikan.

Terlepas dari itu semua, dunia pendidikan harus mampu untuk menyelaraskan antara perkembangan teknologi maupun dengan keterbatasan teknologi dalam meningkatkan kecerdasan interpersonal. Dengan pemanfaatan teknologi yang ada dapat memberikan ruang yang luas untuk meningkatkan kecerdasan interpersonal pada siswa artinya dengan keterbatasan teknologi seorang pendidik bisa membuat suatu terobosan baru dengan 
membuat kebijakan yang di berikan kepada siswa dengan pemanfaatan yang ada di sekitar lingkungan yang dapat dipergunakan dalam pembelajaran, sehingga dengan terbatasnya teknologi tidak menghambat perkembangan belajar siswa yang seharusnya tidak akan menghambat kecerdasan interpersonal pada siswa itu sendiri. Dalam pemanfaatan teknologi yang terus berkembang dalam dunia pendidikan, membuat proses belajar mengajar menjadi daya tarik bagi siswa jika siswa dapat memanfaatkan di alam sekitarnya untuk pembelajaran sehingga pemanfaatan teknologi yang terbatas dapat menjadikan sesuatu yang bermanfaat di lingkungan sekitarnya.

Proses belajar mengajar dengan keterbatasan teknologi sudah tentu akan berpengaruh pada mutu hasil belajar sehingga kurang mendapatkan hasil yang maksimal. Namun dengan pemanfaatan teknologi yang ada di lingkungan sekitar dapat mengubah mutu hasil belajar dengan meningkatkan kecerdasan interpersonal agar bisa saling menghargai. Jadi dengan demikian secara keseluruhan, dengan pemanfaatan teknologi dan keterbatasannya dapat meningkatkan kecerdasan interpersonal dari siswa.

Dampak dari keterbatasan teknologi jika tidak ada pemanfaatannya di lingkungan sekitar akan berpengaruh di dalam dunia pendidikan. Terutama dalam proses belajar mengajar sehingga membuat siswa enggan untuk mengasah kecerdasan interpersonal diri khususnya dalam bersosialisasi dan untuk saling menghargai.

Kecerdasan interpersonal pada setiap siswa tidaklah sama. Tidak semua siswa mampu merasakan apa yang dialami oleh orang lain yang ada di sekitarnya. Siswa yang mampu berempati dan mampu berinteraksi dengan baik berarti memiliki kecerdasan secara interpersonal dalam pemanfaatan teknologi yang ada.

\section{METODOLOGI PENELITIAN}

Metodologi dalam penulisan ini adalah deskriptif, sedangkan variabelnya adalah kecerdasan interpersonal dengan menggunakan pendekatan kualitatif. Subjeknya adalah siswa kelas VIII SMP Negeri 2 Sungai Pinyuh.

\section{PEMBAHASAN}

Data yang digunakan untuk analisis penulisan ini berupa data hasil pemanfaatan keterbatasan teknologi untuk meningkatkan kecerdasan interpersonal siswa dalam pembelajaran matematika pada materi keliling lingkaran. Hasil yang didapat sebagai berikut: dari 10 siswa yang belum memahami dalam pemanfaatan keterbatasan teknologi dalam kecerdasan interpersonal siswa sebanyak 4 orang. Sedangkan yang 6 orang sudah memiliki kecerdasan interpersonal diri dengan memahami dan mengerti secara sosial, dan 4 orang lagi belum memahami mengenai kecerdasan interpersonal pribadi dikarenakan belum terlihatnya rasa untuk memahami dengan orang di sekitarnya.

Berdasarkan uraian di atas dapat dikatakan bahwa pemanfaatan keterbatasan teknologi dapat meningkatkan kecerdasan interpersonal diri.

\section{KESIMPULAN}

Berdasarkan hasil pembelajaran yang telah dilakukan maka dapat ditarik kesimpulan bahwa pemanfaatan keterbatasan teknologi dapat meningkatkan kecerdasan interpersonal.

\section{DAFTAR PUSTAKA}

Azwar, S. (2004). Pengantar Psikologi Inteligensi. Yogyakarta: Pustaka Pelajar

Maksum, Ali. (2011). Pluralisme dan Multikulturalisme: Paradigma Baru Pendidikan Agama Islam di Indonesia. Malang: Aditya Media Publishing.

Muzayanah, A., \& Prestiana, N. D. I. (2008). Hubungan antara Kecerdasan 
Interpersonal dengan Kepuasan Kerja Karyawan (Guru). SOUL: Jurnal Pemikiran dan Penelitian Psikologi, 1 (2), 32-46.

Prasetyo, J. R., \& Andirani, Y. (2009).

Multiply Your Multiple Intelligences
Melatih 8 Kecerdasan Majemuk pada Anak dan Dewasa. Yogyakarta: Andi Offset. 